$\begin{array}{ll}\text { Volume } & : 04 \\ \text { Nomor } & : 023 \\ \text { Bulan } & : \text { September } \\ \text { Tahun } & : 2018 \\ \text { http } & : \text { //ejurnal.pps.ung.ac.id/index.php/AKSARA/index }\end{array}$

\title{
Implementasi Pendidikan Karakter Siswa Sekolah Dasar di Indonesia
}

\author{
Salma Halidu, Polan M. Dehi, Abdul Rahmat, Mira Mirnawati \\ Universitas Negeri Gorontalo \\ abdulrahmat@gmail.com
}

\begin{abstract}
Abstrak
Tujuan penelitian ini adalah untuk mendeskripsikan implementasi pendidikan karakter di sekolah dasar. Penelitian ini menggunakan metode deskriptif kualitatif yang bertujuan mendeskripsikan implementasi pendidikan karakter di sekolah dasar. Instrument penelitian ini menggunakan observasi, wawancara dan dokmentasi. Hasil penelitian menunjukan bahwa implementasi pendidikan karakter di sekolah dasar sudah baik, dilakukan dengan mengintegrasikan nilai-nilai karakter ke dalam perangkat pembelajaran seperti silabus, RPP, dan saat kegiatan pembelajaran, selain itu implementasi pendidikan karakter tidak hanya dilakukan di dalam kelas tapi juga dilakukan di luar kelas, seperti kegiatan upacara bendera yang dilaksanakan setiap hari Senin, kegiatan ekstrakulikuler Kepramukaan, Palang Merah Remaja, dan kerja bakti. Dengan mengangkat nilai mandiri, peduli lingkungan, cinta tanah air dan bersahabat. Dengan demikian dapat disimpulkan bahwa implementasi pendidikan karakter sudah berjalan dengan baik dan diterapkan oleh anak di lingkungan rumah, sekolah dan masyarakat.
\end{abstract}

Kata Kunci: Implementasi, Pendidikan Karakter, dan Prestasi

\section{PENDAHULUAN}

Pendidikan dilaksanakan bukan sekedar untuk mengejar nilai-nilai melainkan memberikan pengarahan kepada setiap orang agar dapat bertindak dan bersikap benar sesuai dengan kaidah dan aturan yang berlaku. Berbudi luhur sama artinya dengan berakhlak atau berkarakter baik dimana karakter dapat dimaknai sebagai cara berfikir dan berperilaku manusia untuk hidup dan bekerjasama baik dalam lingkup keluarga, masyarakat, bangsa dan Negara. Manusia yang berkarakter baik adalah manusia yang mampu membuat keputusan dan mempertanggungjawabkan akibat dari keputusannya. Sehingga diperlukan adanya pendidikan karakter disetiap jenjang pendidikan mulai dari anak usia dini sampai dengan perguruang tinggi untuk membentuk karakter bangsa menjadi jauh lebih baik dari apa yang diharapkan oleh semua pihak seperti yang diungkapkan oleh (Prasetyo dan Rivasintha, 2011: 2) yang menyatakan bahwa Pendidikan karakter adalah suatu sistem penanaman nilai-nilai karakter kepada warga sekolah yang meliputi komponen pengetahuan, kesadaran atau kemauan, dan tindakan untuk melaksanakan nilai-nilai tersebut, baik terhadap Tuhan Yang Maha Esa (YME), diri sendiri, sesama, lingkungan, maupun kebangsaan sehingga menjadi manusia insan kamil. Artinya Penyelenggaraan pendidikan karakter menjadi satu hal yang multlak dilakukan di jenjang pendidikan manapun, khususnya di jenjang pendidikan dasar. Hal ini sangat beralasan karena pendidikan dasar adalah pondasi utama bagi tumbuh kembang generasi muda Indonesia. Namun kenyataannya tidak sesuai harapan, hal ini dapat di lihat dari situasi sosial kultural masyarakat yang akhir-akhir ini. 


$\begin{array}{ll}\text { Volume } & : 04 \\ \text { Nomor } & : 03 \\ \text { Bulan } & : \text { September } \\ \text { Tahun } & : 2018 \\ \text { http } & : \text { //ejurnal.pps.ung.ac.id/index.php/AKSARA/index }\end{array}$

Barbagai macam peristiwa dalam pendidikan yang menciptakan manusia yang berkualitas baik dalam ilmu pengetahuan, teknologi maupun agama namun sering disalah gunakan seperti hancurnya nilai-nilai moral. Bahkan yang lebih parahnya lagi kebanyakan para pelaku dari hancurnya nilai-nilai karakter dilakukan oleh orang-orang yang berpendidikan. Ini dapat di lihat dari banyaknya ketidakadilan, kurangnya rasa solidaritas, kebiasaan menyontek, banyaknya sampah yang masih berserakan di lingkungan, masih ada siswa yang tidak mengikuti upacara bendera, masih ada siswa yang saling mengolok-olok. Bahkan ditingkat yang lebih tinggi sendiri, yaitu pemerintah yang tak mengenal lagi sebuah karakter diri sebagai makhluk Tuhan dan sosial.

Berdasarkan observasi awal yang dilakukan peneliti di SDN 1 Bongomeme pada tanggal 9 Februari 2016, peneliti menjumpai beberapa masalah yang menarik mengenai karakter siswa. Selanjutnya peneliti melakukan wawancara dengan kepala sekolah mengenai implementasi nilai-nilai karakter di sekolah ini. Dan sesuai hasil wawancara yang dilakukan bahwa nilai-nilai karakter yang ada di SDN 1 Bongomeme telah di integrasikan ke dalam perangkat pembelajaran, seperti silabus, RPP dan proses pelaksanaan pembelajaran. Selain itu pendidikan karakter tidak hanya dilakukan melalui pembelajaran di dalam kelas tapi juga dilakukan di luar kelas, seperti kegiatan upacara penaikan bendera yang dilaksanakan setiap hari Senin, kegiatan ekstrakulikuler kepramukaan, PMR, dan juga pada kegiatan kerja bakti dll. Meski begitu masih ada saja tingkah laku siswa yang kurang berkarakter seperti yang peneliti jumpai berupa perilaku siswa yang tidak bertanggung jawab dalam menegerjakan tugas individu yang diberikan guru, siswa yang suka mengganggu teman, siswa yang sembarangan membuang sampah hanya ketika ada guru yang melihat siswa tersebut akan membuang sampah pada tempatnya, namun ketika tidak ada guru siswa tersebut membuang sampah tidak pada tempatnya, siswa yang suka bermain saat upacara bendera dilaksanakan, dan lainnya. Dengan masalah yang telah diungkap oleh peneliti, maka peneliti mengangkat judul "Implementasi Pendidikan Karakter Di Sekolah Dasar". Peneliti berharap semua masalah dapat diatasi dengan baik dengan adanya kerjasama antara pihak sekolah, orang tua, masyarakat dan pemerintah. Selain itu peran orang tua juga sangat penting untuk membentuk karakter anak, karena sebagian besar anak menghabiskan waktunya di rumah.

Sesuai latar belakang masalah yang diuraikan di atas, maka rumusan masalah pada penelitian ini adalah: bagaimana gambaran pentingnya implementasi pendidikan karakter di SDN 1 Bongomeme Kabupaten Gorontalo? Nilai karakter apa saja yang dikembangkan pada siswa? Bagaimana implementasi pendidikan karakter di sekolah dasar khususnya nilai mandiri, peduli lingkungan, cinta tanah air dan bersahabat?

\section{KAJIAN TEORITIS}

Ki Hadjar Dewantara seperti dikutip Abu Ahmadi dan Nur Ukhbiyati (Kurniawan, 2013: 27) mendefinisikan pendidikan sebagai tuntutan segala kekuatan kodrat yang ada pada anak agar mereka kelak menjadi manusia dan anggota masyarakat yang dapat mencapai keselamatan dan kebahagiaan yang setinggi-tingginya. 


$\begin{array}{ll}\text { Volume } & : 04 \\ \text { Nomor } & : 023 \\ \text { Bulan } & : \text { September } \\ \text { Tahun } & : 2018 \\ \text { http } & : \text { //ejurnal.pps.ung.ac.id/index.php/AKSARA/index }\end{array}$

Hal yang sama diuraikan H. Mangun Budiyanto (Kurniawan, 2013: 27) yang berpendapat bahwa pendidikan adalah mempersiapkan dan menumbuhkan anak didik atau individu manusia yang prosesnya berlangsung secara terus-menerus sejak ia lahir sampai ia meninggal dunia. Aspek yang dipersiapkan dan ditumbuhkan itu meliputi aspek badannya, akalnya, rohani sebagai suatu kesatuan tanpa mengesampingkan salah satu aspek dan melebihkan aspek yang lain.

Menurut Abidin (2012:56), bahwa "pendidikan karakter dimaknai sebagai pendidikan yang mengembangkan nilai-nilai karakter pada diri peserta didik sehingga mereka memiliki nilai dan karakter sebagai karakter dirinya, menerapkan nilai-nilai tersebut dalam kehidupan dirinya, sebagai anggota masyarakat, dan warga negara yang religius, nasionalis, produktif, dan kreatif.

Semetara itu, menurut Zubaedi (Kurniawan, 2013: 30) pendidikan karakter adalah pendidikan budi pekerti plus, yang intinya merupakan program pengajaran yang bertujuan mengembangkan watak dan tabiat peserta didik dengan cara menghayati nilai-nilai dan keyakinan masyarakat sebagai moral dalam hidupnya melalui kejujuran, dapat dipercaya, didisiplin, dan kerja sama yang meningkatkan ranah afektif (perasaan/sikap) tanpa meninggalkan ranah kongnitif (berfikir rasional), dan ranah skill(keterampilan, terampil mengolah data, mengemukakan pendapat, dan kerjasama).

Budi pekerti adalah watak atau tabiat khusus seseorang untuk berbuat sopan dan menghargai pihak lain yang tercermin dalam perilaku dan kehidupannya. Sementara watak merupakan keseluruhan dorongan, sikap, keputusan, kebiasaan, dan nilai moral seseorang yang baik.

Definisi ini senada dengan definisi yang dirumuskan oleh Suyanto (Kurniawan 2013: 31), yang merumuskan pendidikan karakter sebagai pendidikan budi pekerti plus, yaitu yang melibatkan aspek pengetahuan (congnitive), perasaan (feeling), dan tindakan (action).

Dari pendapat yang di ungkap di atas maka menurut peneliti pendidikan karakter adalah suatu proses untuk mendidik peserta didik menjadi insan yang lebih baik yang terwujud dari nilai-nilai karakter di sekolah dan bisa di terapkan dalam kehidupannya sehari-hari di lingkungan rumah, sekolah maupun di lingkungan masyarakat.

Menurut (Fathurrohman, dkk 2013: 97) Pendidikan karakter pada tingkatan institusi mengarah pada pembentukan karakter sekolah, yaitu nilai-nilai yang melandasi perilaku, tradisi, kebiasaan keseharian, dan simbol-simbol yang dipraktikkan oleh semua warga sekolah, dan masyarakat sekitar sekolah. Karakter sekolah merupakan ciri khas, karakter atau watak, dan citra sekolah tersebut di mata masyarakat luas. Menurut Kurniawan 2013: 127, pendidikan karakter di lingkungan sekolah bertujuan untuk meningkatkan mutu penyelenggaraan dan hasil pendidikan di sekolah yang mengarah pada pencapaian pembentukan karakter dan akhlak mulia peserta didik secara utuh, terpadu, dan seimbang, sesuai standar kompetensi lulusan.

Pengembangan pendidikan karakter di sekolah pada dasarnya adalah mengusahakan agar peserta didik mengenal dan menerima nilai-nilai karakter sebagai milik mereka dan bertanggung jawab atas keputusan yang diambilnya 


$\begin{array}{ll}\text { Volume } & : 04 \\ \text { Nomor } & : 03 \\ \text { Bulan } & : \text { September } \\ \text { Tahun } & : 2018 \\ \text { http } & : \text { //ejurnal.pps.ung.ac.id/index.php/AKSARA/index }\end{array}$

melalui tahapan mengenal pilihan, menilai pilihan, menentukan pendirian, dan selanjutnya menjadikan suatu nilai menjadi keyakinan diri.

Dalam membentuk karakter bangsa diperlukan upaya yang sungguh-sungguh untuk membangun karakter individu (warga negara). Karakter individu yang dijiwai oleh sila-sila Pancasila dapat dikemukakan sebagai berikut: (1) Karakter yang bersumber dari olah hati, antara lain beriman dan bertaqwa, jujur, amanah, adil, tertib, tata aturan, bertanggung jawab, berempati, berani mengambil resiko, pantang menyerah, rela berkorban, dan berjiwa patriotic, (2) Karakter yang bersumber dari oleh pikir antara lain cerdas, kritis, kreatif, inovatif, ingin tahu, produktif, berorientasi Iptek, dan refleksi. (3) Karakter yang bersumber dari olah raga/kinestika antara lain bersih, sehat, sportif, tangguh, andal,berdaya tahan, bersahabat, kooperatif, deterninatif, kompetitif, ceria, gigih, dan (4) Karakter yang bersumber dari olah rasa/karsa antar lain kemanusiaan, saling menghargai, gotong royong, kebersamaan, ramah, toleran, nasionalis, peduli, kosmopolit (mendunia), mengutamakan kepentingan umum, cinta tanah air (patriotis), bangga menggunakan bahasa dan produk Indonesia, dinamis, kerja keras, dan beretos kerja tinggi. (Hafid. Jafar Ahiri. Pendais Haq, 2013: 113-114)

\section{METODE PENELITIAN}

Pendekatan yang digunakan dalam penelitian ini adalah pendekatan deskriptif kualitatif dengan jenis penelitian kualitatif dimana semua kejadian - kejadian yang didapatkan di lapangan digambarkan dengan kata - kata. Dalam penelitian ini jenis penelitian yang digunakan adalah observasi, wawancara, dan dokumentasi untuk mengumpulkan data-data demi kelengkapan peneliti.

Lofland (Moleong, 2004: 157) menyatakan bahwa sumber data dalam penelitian kualitatif yaitu berupa kata-kata, dan tindakan selebihnya adalah data tambahan seperti dokumen dan lain-lain. Yang akan dijadikan sumber data salah satunya adalah manusia yang dijadikan informan. Informan dalam peneliti ini yaitu kepala sekolah, guru dan orang tua siswa di SDN 1 Bongomeme. Dalam penelitian ini yang menjadi sumber data yakni ada dua yaitu; Data Primer, yaitu data yang diperoleh melalui observasi wawancara dengan kepala sekolah, guru, orang tua siswa, siswa yang dapat memberikan informasi sehubungan dengan masalah yang akan diteliti yaitu implementasi pendidikan karakter. Data Sekunder yaitu data yang akan diperoleh secara tertulis yang dapat melalui buku referensi berupa pengertian dan teori - teori yang hubungannya dengan permasalahan yang teliti pakai. Data Sekunder disebut data yang seperti dokumen profil sekolah dan arsip - arsip lain yang nyata sesuai dengan topik kajian dalam penelitian ini.

Analisis data dalam penelitian kualitatif dilakukan sejak sebelum memasuki lapangan, selama di lapangan, dan setelah selesai di lapangan. Dalam hal ini Nasution 1988 (Sugiyono 2014: 245) menyatakan "analisi telah dimulai sejak merumuskan dan menjelaskan masalah, sebelum terjun ke lapangan, dan berlangsung terus sampai penulisan hasil penelitian. Ada beberapa hal yang diperlukan dalam analisis data ini yaitu reduksi data dan verifikasi data. Reduksi data maksudnya memilah - milah data yang pokok dari data tersebut dan verifikasi data, artinya menyimpulkan dan memberikan tafsiran atau memaknai data yang terkumpul. 


$\begin{array}{ll}\text { Volume } & : 04 \\ \text { Nomor } & : 023 \\ \text { Bulan } & : \text { September } \\ \text { Tahun } & : 2018 \\ \text { http } & : \text { //ejurnal.pps.ung.ac.id/index.php/AKSARA/index }\end{array}$

\section{HASIL PENELITIAN DAN PEMBAHASAN Hasil penelitian}

Dari hasil wawancara yang dilakukan diperoleh data bahwa dalam implementasi pendidikan karakter di SDN 1 Bongomeme sudah baik, namun meski masih terdapat beberapa masalah dalam mengimplemntasikan nilai-nilai karakter utamanya pada kemandirian siswa, kepedulian terhadap lingkungan, sikap cinta tanah air ataupun sikap bersahabat dalam kesehariannya di sekolah. Adapun masalah yang sering muncul diantaranya siswa yang sering datang terlambat apalagi pada hari senin dilaksanakan upacara bendera, masih ada siswa yang suka melihat atau menyontek jawaban temannya, masih ada siswa yang tidak mengerjakan tugasnya secara mandiri, masih ada siswa yang tidak melaksanakan piket kebersihan kelas, masih ada siswa yang belum hafal tentang lagu nasional, masih ada siswa yang tidak memakai atribut lengkap saat mengikuti upacara serta masih ada saja siswa yang suka membuat keributan di dalam kelas saat tidak ada gurunya.

Adapun cara atau strategi yang dilakukan guru yaitu dengan melakukan pembiasaan atau memberikan contoh atau teladan yang baik pada siswanya. Guru membuat peraturan yang ada di dalam kelas berdasarkan kesepakatan bersama dengan siswa, sehingga jika ada siswa yang melanggar maka akan diberikan sanksi sesuai dengan kesalahan yang dia lakukan, guru memberikan bimbingan, nasehat, dan arahan kepada siswa, selain itu guru dan orang tua siswa bekerjasama dalam mengawasi tingkah laku anak sehingga nilai-nilai karakter yang sudah diajarkan di sekolah tidak akan berpengaruh ketika berada di dalam sekolah maupun diluar sekolah.

\section{Pembahasan}

\section{Pentingnya Implementasi Pendidikan Karakter di Sekolah Dasar}

Pentingnya implementasi pendidikan karakter di sekolah dasar berdasarkan temuan peneliti bahwa dalam membentuk pribadi peserta didik yang berperilaku baik, bersikap baik, berakhlak mulia, berbudi pekerti luhur, bermoral perlu ditanamkan kepada anak sejak usia dini. Hal ini dikarenakan pendidikan karakter adalah proses untuk mendidik peserta didik menjadi insan yang lebih baik yang terwujud dari nilai-nilai karakter di sekolah dan bisa di laksanakan dalam kehidupannya sehari-hari di lingkungan rumah, sekolah maupun di lingkungan masyarakat. Adapun sikap atau perilaku yang diharapkan dalam mengimplementasikan keberhasilan pendidikan karakter adalah agar siswa menjad pribadi yang berkarakter baik, bermoral, berperilaku dengan kaidah dalam bermasyarakat dan berbangsa yang sesuai dengan tujuan pendidikan nasional. Adapun tujuan yang sama dikemukakan oleh Ramli 2003 (Fathurrohman, dkk 2013:15), pendidikan karakter memliki esensi dan makna yang sama dengan pendiddikan moral dan pendidikan akhlak. Tujuannya adalah membentuk pribadi anak, supaya menjadi manusia yang lebih baik, warga masyarakat yang baik.

Karakter yang berkualitas perlu dibentuk dan dibina sejak usia dini. Usia dini merupakan masa kritis bagi penanaman karakter seseorang. Banyak pakar mengatakan bahwa kegagalan penanaman karakter sejak usia dini akan membentuk 


$\begin{array}{ll}\text { Volume } & : 04 \\ \text { Nomor } & : 03 \\ \text { Bulan } & : \text { September } \\ \text { Tahun } & : 2018 \\ \text { http } & : \text { //ejurnal.pps.ung.ac.id/index.php/AKSARA/index }\end{array}$

pribadi yang bermasalah dimasa dewasanya kelak. Oleh karena itu, penanaman moral melalui pendidikan karakter sedini mungkin kepada anak-anak adalah kunci utama untuk membangun bangsa yang berkarakter yang sesuai dengan tujuan pendidikan nasional.

\section{Karakter yang di Kembangkan di Sekolah Dasar pada siswa}

Temuan penelitian terhadap karakter yang dikembangkan di sekolah dasar pada siswa adalah nilai kemandirian siswa, kepedulian siswa terhadap lingkungan, rasa cinta tanah air dan bersahabat. Berikut ini temuan yang diperoleh dari hasil penelitian:

a. Nilai mandiri

Nilai mandiri sangat penting untuk diimplementasikan di sekolah dasar untuk menanamkan sikap percaya diri, tanggung jawab kepada siswa, sehingga siswa tidak akan bergantung pada orang lain dalam menyelesaikan tugastugasnya.

Maka jika dianalisis dari hasil wawancara mengenai nilai mandiri yang diimplementasikan atau dikembangkan pada siswa di SDN 1 Bongomeme ini berupa kegiatan pemberian tugas terstruktur maupun tidak terstruktur, tugas lisan maupun tulisan, pembiasaan salam jika bertemu guru, bertutur kata sopan dengan guru dan teman, ada juga pembiasaan sebelum masuk kelas siswa dibiasakan berjabatan tangan dengan bapak ibu guru, ada juga kegiatan ekstrakulikuler yang mengharuskan siswa untuk bertindak mandiri.

Analisis dari hasil wawancara mengenai kegiatan yang dilaksanakan di sekolah untuk menanamkan karakter mandiri itu telah dilaksanakan dan berjalan dengan baik. Siswa SDN 1 Bongomeme mengikuti rangkaian kegiatan yang telah diterapkan oleh sekolah dan menjalankannya sehingga karakter mandiri sudah tertanam pada diri siswa. Kemandirian dalam belajar perlu ditanamkan kepada siswa agar mereka mempunyai tanggung jawab dalam mengatur dan mendisiplinkan diri dalam kemampuan belajar atas kemauan sendiri. Seperti halnya pendapat yang dikemukakan oleh Wedemeyer yang dikutip Keegan (Kurniawan, 2013:126), peserta didik yang belajar secara mandiri mempunyai kebebasan untuk belajar tanpa harus menghadiri pelajaran yang diberikan guru/instruktur di kelas. Peserta didik dapat mempelajari pokok bahasan atau topik pelajaran tertentu dengan membaca buku atau melihat buku dan mendengarkan media pandang dengar (audio visual) tanpa bantuan atau dengan bantuan terbatas dari orang lain.

b. Berdoa sebelum belajar dan pulang sekolah

Semua kegiatan harus diawali dan diakhiri dengan berdoa agar apa yang diharapkan mendaptkan berkah dan rahmat dari Allah. Dari hasil observasi yang dilakukan oleh peneliti, peneliti melihat, mengamati dan memperhatikan bahwa untuk kegiatan berdoa sebelum mengawali dan mengakhiri pelajaran telah berjalan setiap harinya. Semua siswa diwajibkan khusuk dan sungguh-sungguh dalm berdoa agar pelajaran yang diajarkan dapat bermanfaat dikemudian hari. Adapun tujuan dari kegiatan ini yaitu agar kegiatan pembelajaran nantinya akan dilaksanakan mendapat berkah dari Allah SWT dan manfaat di kemudian hari, 


$\begin{array}{ll}\text { Volume } & : 04 \\ \text { Nomor } & : 023 \\ \text { Bulan } & : \text { September } \\ \text { Tahun } & : 2018 \\ \text { http } & : \text { //ejurnal.pps.ung.ac.id/index.php/AKSARA/index }\end{array}$

selain itu juga agar para siswa terbiasa untuk bersyukur kepada Allah atas kegiatan-kegiatan yang masih bisa dilakukan oleh siswa.

c. Senyum, salam, sapa, sopan, santun, syukur

Kegiatan senyum, salam, sapa, sopan, santun dan syukur merupakan rangkaian kebudayaan yang perlu ditanamkan atau diterapkan kepada siswa agar siswa memiliki akhlak yang baik kepada sesamanya, khususnya kepada guru atau temannya. Sehingga ketika siswa masuk ke lingkungan sekolah maka siswa memberikan salam, menyapa, dan senyum dan berjabatan tangan dengan guru serta bertutur kata sopan. Dari hasil observasi yang dilakukan oleh peneliti, peneliti melihat, mengamati dan memperhatikan bahwa untuk kegiatan senyum, salam, sapa, sopan, santun, dan syukur dilakakukan melalui pembiasaan dan pembudayaan sudah berjalan dengan sangat baik. Adapun tujuan dari kegiatan ini yaitu untuk menjelaskan kepada siswa bagaimana berperilaku ketika bertemu dengan guru, orang yang lebih tua, maupun teman-temannya baik di sekolah maupun di rumah ataupun di masyarakat sekitar.

\section{Implementasi Nilai-Nilai Karakter di Sekolah Dasar}

Temuan penelitian terhadap cara dalam mengimplementasikan pendidikan karakter di sekolah dasar yaitu dengan cara pemberian keteladanan/pemberian contoh, pembiasaan, pemberian arahan, bimbingan dan motivasi. Dimana keteladanan merupakan salah satu faktor yang dapat menentukan keberhasilan pendidikan karakter. Guru tidak hanya berperan sebagai pemberi materi pelajaran kepada siswanya tetapi juga memberikan teladan/contoh yang baik. Salah satu cara/strategi guru dalam mengimplementasikan karakter kepada siswa baik itu pada saat pembelajaran berlangsung, maupun pada kegiatan ekstrakulikuler adalah dengan cara menjadi teladan/contoh yang baik bagi siswa. Seperti yang dikemukakan oleh Usman (2009:13) bahwa "peran guru sebagai pribadi salah satunya adalah sebagai teladan yaitu yang senantiasa mencarikan teladan yang baik bagi siswanya. Oleh sebab itu, guru menjadi ukuran bagi norma-norma tingkah laku". Guru menjadi teladan/contoh yang baik agar siswa dapat mencontoh perilaku baik gurunya. Karena biasanya anak usia sekolah dasar mereka paling suka meniru apa yang dilakukan oleh gurunya, guru itu adalah idola bagi siswanya jadi sebelum guru menanamkan karakter pada siswa guru itu haruslah terlebih dahulu berkarakter dan memberikan contoh yang baik kepada siswa. Untuk pembiasaan kepada siswa guru tanpa mengenal lelah atau jenuh memberikan pengarahan dan contoh kepada siswa agar menjadi terbiasa berkarakter, baik itu dalam perbuatan, sikap, tingkah laku, tutur kata dan lainnya. Dan untuk pemberian arahan, bimbingan dan motivasi dilakukan oleh guru tidak hanya ketika siswa melakukan kesalahan namun setiap harinya.

Dari hasil wawancara dan pengamatan peneliti bahwa cara dalam mengimplementasikan nilai karakter di sekolah dasar telah dilakukan oleh guru dengan baik dan maksimal namun dikarenakan waktu siswa di sekolah terbatas maka untuk bisa mencapai karakter yang diharapkan yang sesuai dengan tujuan pendidkan nasional butuh kerjasama dengan orang tua. 


$\begin{array}{ll}\text { Volume } & : 04 \\ \text { Nomor } & : 03 \\ \text { Bulan } & : \text { September } \\ \text { Tahun } & : 2018 \\ \text { http } & : \text { //ejurnal.pps.ung.ac.id/index.php/AKSARA/index }\end{array}$

\section{PENUTUP}

Hasil penelitian menunjukan bahwa implementasi pendidikan karakter di sekolah dasar SDN 1 Bongomeme telah berjalan dengan baik. Berdasarkan hasil penelitian dan pengelolaan data yang dilakukan oleh peneliti maka dapat disimpulkan bahwa secara umum dalam proses implementasi nilai-nilai karakter telah berjalan dengan baik, yaitu dengan mengintegrasikan nilai-nilai karakter dalam pembelajaran maupun pada kegiatan ekstrakulikuler, memberikan pembiasaan tentang hal baik, pemberian teladan/contoh, motivasi atau dorongan dan bimbingan kepada siswa untuk berkarakter baik. Berdasarkan kesimpulan, maka saran yang dapat disampaikan oleh peneliti Bagi guru dapat dijadikan sumber panduan untuk lebih berperilaku baik sesuai dengan karakter yang diharapkan agar bisa menjadi contoh/teladan yang baik bagi siswanya. Kepala sekolah dan guru hendaknya saling mengingatkan untuk terus menerus mendampingi siswa dalam membimbing, memotivasi, mengarahkan dan mendidik siswanya untuk tetap berkaraker baik di lingkungan sekolah, keluarga ataupun lingkungan masyarakat.

\section{DAFTAR PUSTAKA}

Hafid, Anwar. Jefri Ahiri dan Pendais Haq. 2013. Konsep Dasar Ilmu Pendidikan. Bandung: Alfabeta.

Abidin, Y. 2012. Pembelajaran Bahasa Berbasis Pendidikan Karakter. Bandung: Refika Aditama

Daryanto, dan Darmiatun S. 2013. Implementasi Pendidikan Karakter di Sekolah. Yokyakarta. Gava Media

Kurniawan, Syamsul. 2013. Pendidikan Karakter: Konsepsi Dan Implementasi Secara Terpadu Dilingkungan Keluarga, Sekolah, Perguruan Tinggi, Dan Masyarakat. Yogyakarta: AR-RUZ Media.

Wibowo, Agus. 2012. Pendidikan Karakter: Strategi Membangun Karakter Bangsa Berperadaban. Yogyakarta: Pustaka Pelajar

Zubaedi. 2011. Desain Pendidikan Karakter: Konsepsi dan Aplikasinya dalam Lembaga Pendidikan. Jakarta: Kencana

Prasetyo, Agus dan Emusti Rivasintha. "Konsep, Urugensi, dan Implementasi Pendidikan Karakter di Sekolah”. Dalam http://edukasi.kompasiana.com

Mulyasa. 2014. Manajemen pendidikan Karakter. Jakarta: Bumi Aksara.

Fathurrohman, Pupuh. AA Suryana. Fenny Fatriany. 2013. Pengembangan Pendidikan Karakter. Bandung: Refika Aditama

Moleong, L. J. 2013. Metodologi Penelitian Kualitatif. Bandung: Remaja Rosdakarya

UNG. 2015. Panduan Karya Ilmiah. Universitas Negeri Gorontalo

Litiloli, S. 2016. Upaya Guru dalam Pembentukan Karakter Siswa di SDN No. 85 Kota Tengah Kota Gorontalo. Skripsi. Universitas Negeri Gorontalo

Zubaedi,.2011. Desain Pendidikan karakter. Jakarta: Kencana Prenada Media Group

Sugiyono. 2014. Metode Penelitian Kuantitatif Kualitatif dan $R \&$ D. Alfabeta. Bandung

Sugiyono. 2011. Metode Penelitian Pendidikan (Pendekatan Kantitatif Kualitatif $R \& D)$. Alfabeta. Bandung 